\title{
The Rise of a European Healthcare Union
}

Vollaard, Hans; Martinsen, Dorte Sindbjerg

Published in:

Comparative European Politics

DOI:

10.1057/cep.2016.3

Publication date:

2017

Document version

Peer reviewed version

Citation for published version (APA):

Vollaard, H., \& Martinsen, D. S. (2017). The Rise of a European Healthcare Union. Comparative European Politics, 15(3), 337-352. [1]. https://doi.org/10.1057/cep.2016.3 


\title{
The Rise of a European Healthcare Union ${ }^{1}$
}

\author{
Hans Vollaard ${ }^{\alpha *}$ and Dorte Sindbjerg Martinsen ${ }^{\beta}$ \\ Introduction for Special Issue (2016) in Comparative European Politics

\section{http://www.palgrave-journals.com/cep/journal/vaop/ncurrent/pdf/cep20163a.pdf}

\section{Abstract:}

Healthcare has only slowly appeared on the EU's policy agenda. EU involvement in policies concerning the organization, financing, and the provision of diagnosis, care, and cures to ill people developed along three fragmented tracks: a. EU public health policies concerning the well-being of all people; $b$. the application of the free movement principle to national healthcare systems in particular by the EU's Court of Justice (CJEU); and c. the austerity packages and the stricter EU surveillance of national budgets since the debt crises. The key questions of this special issue are whether this fragmented EU involvement has now developed into a distinct European healthcare union, and if so, what its driving forces have been. Thus, it explores how European integration in healthcare has moved forward despite widespread reluctance. It also examines the underexplored political dynamics and implementation of CJEU case law. The conclusion is that a fragile European healthcare union is emerging. A distinct area of EU health law has come into existence, whereas an institutional structure has given a voice to health expertise. A certain commonality in patients' rights has also emerged. The EU's budgetary surveillance deeply intrudes into healthcare policies, but here, the involvement of health actors has remained limited. The European Commission and the CJEU have played an important role in the European integration of healthcare policies, but reluctance towards EU intrusion into national healthcare systems left an emphatic mark on CJEU case law, its codification in EU law and its implementation. Variants of the multiple streams approach appeared to be helpful to explain this evolution.

\footnotetext{
${ }^{\alpha} *$ Corresponding author. The Institute of Political Science, Leiden University, Wassenaarseweg 52, 2333 AK Leiden, The Netherlands. Email: vollaard@fsw.leidenuniv.nl

${ }^{\beta}$ Department of Political Science, University of Copenhagen, Øster Farimagsgade 5, 1353 København K, Denmark.dm@ifs.ku.dk
} 
The economic and monetary union, the European banking union, the European the solidarity union, the European democratic union, the European innovation union, the European fiscal union, the European defence union, the European capital markets union, the European energy union, the European political union... the European Union (EU) has produced an abundance of unions, although some unions are more developed than others. Despite all of the legitimacy and debt crises, European integration still advances. However, does this advance also hold true for healthcare, even if many people prefer to almost exclusively maintain national control? The rise of a "new compound European healthcare state" has already been observed (Lamping 2005, 43). Thus, is a European healthcare union in the making, and if so, what are its driving forces? These are the key questions of this special issue.

The concept of a European healthcare union consists of three components (cf. Vollaard, Van de Bovenkamp, and Martinsen 2015). The first component, European, refers to the EU. Healthcare involves the organization, financing, and the provision of diagnosis, care, and cures to ill people, including pharmaceuticals and medical devices. Healthcare should thus be distinguished from the closely related area of public health, which includes all policy measures to increase the physical and mental well-being of all people (such as anti-pollution policies). The final component, union, refers to a commonality that makes a collection of units (in casu healthcare systems) a distinct entity. First, this commonality may vary in nature. Concerning healthcare unions, commonality may involve the common use by professionals, patients or other actors of healthcare systems, the common values and standards that guide these healthcare systems, the union's common institutions for healthcare policy-making, or a common regulation or financing of (parts of) the healthcare systems. Second, a union may also vary in strength. Commonality will be stronger if standards, values, guidelines, and legislation are more binding and the units are more mutually dependent and tied to one another.

Healthcare is one of the least likely cases of European unification (Martinsen 2005, 1036). For a long time, there was no explicit reference to healthcare in the treaties of the EU and its predecessors. The EU was not expected to interfere in the healthcare systems of the 
member states (Martinsen and Falkner 2011). Since the Single European Act (in force since 1987), these treaties have included the general principle to maintain a high level of health protection in the activities and policies of the EU, but only the Maastricht Treaty (in force since 1993) provided a legislative base for the EU's supplementary role in the related area of public health. Only when national governments and parliaments felt that their healthcare prerogatives were threatened in the late 1990s, they amended the treaties to restrain EU involvement in healthcare. The present version of the Treaty of the Functioning of the European Union states (TFEU) in Article 168(7) that "[t]he Union should respect the responsibilities of the Member States for the definition of their health policy and for the organization and delivery of health services and medical care. The responsibilities of the Member States shall include the management of health services and medical care and the allocation of the resources assigned to them." In addition to national governments and parliaments, a considerable majority of the population in the EU prefers national decisionmaking on healthcare over EU involvement (European Commission, 2010). Furthermore, few EU citizens have sought planned healthcare in another EU member state (Rosenmöller et al., 2006; European Commission, 2015). Perhaps for these reasons, there has been only limited support from civil society organizations in favour of EU legislation of healthcare issues, such as patient mobility (Greer and Rauscher 2011: 235). Moreover, the Directorate-General of the European Commission that is responsible for health issues, the DG SANTÉ, is not known to be very strong. Expanding the EU's role in healthcare policies is thus rather unlikely given the narrow legal basis and the limited set of relatively weak advocates.

However, healthcare has slowly appeared on the EU's policy agenda since the 1990s (Hervey and Vanhercke, 2010). EU involvement in healthcare policies initially developed along two different tracks. a. EU public health policies concerning issues such as AIDS, cancer, smoking, blood safety, BSE, SARS, Ebola, and ageing were partly based on the policy networks of health professionals (Lamping and Steffen, 2009; Trubek et al, 2009); b. The second track is the application of the principle of free movement in the EU's internal market to national healthcare systems in particular by the Court of Justice of the European Union (CJEU) at the request of the national courts (Brooks, 2012; Leibfried, 2010; Martinsen, 2005). The resulting EU role in healthcare constituted a "law and policy patchwork" (Hervey and Vanhercke, 2010). In recent years, two major developments have marked the EU's involvement in 
healthcare policies. Early on, the EU's predecessors co-regulated the access to healthcare systems and the recognition of pharmaceuticals, diplomas of health professionals, and medical devices in the internal market. However, in response to a series of CJEU verdicts since 1998, the EU eventually adopted in 2011 a directive that should facilitate access to healthcare services in the EU, which reaches the heart of healthcare provision. ${ }^{2}$ Additionally, the EU expanded its role in healthcare policies along a third track, as part of the austerity packages and the stricter EU surveillance of national budgets since the debt crises (Greer, 2014). The question is therefore whether and how the previous patchwork has now been replaced by a healthcare union with a distinct and common set of institutions, regulations, values, and practices.

This up-to-date empirical overview of a European healthcare union in the making serves several purposes. First, this overview provides the necessary input for normative discussions on the desirability and justifiability of the nature and level of EU involvement in healthcare policies. Should healthcare be primarily considered a heavy budgetary burden, a prerequisite of economic growth, the centre of innovative research, or an expression of solidarity between the sick and the healthy and the rich and the poor? Moreover, should solidarity, budget, economic growth, and innovation be mostly a European or national (or regional) matter? If they are addressed at all, these fundamental choices in the organization of a European healthcare union are often a matter of fragmented, technocratic and depoliticized debates that are dominated by policy experts (Hervey and Vanhercke, 2010: 129-130). Even if policy experts can significantly disagree - for example, on the issue regarding whether the EU can define and enforce common standards concerning the quality of care (Vollaard, van de Bovenkamp, and Vrangbæk 2013) - policy discussions may still evolve in a direction that is different than if the discussion would have been politicized and the greater public would have been directly involved. This evolution may be even more accurate given the reluctance of the mass public towards a (larger) EU role in healthcare policies.

Public reluctance towards EU involvement in healthcare also provides the theoretical relevance of an exploration of the European healthcare union in this special issue. How can European integration advance in a period in which the politicization of European integration and the adherence to national identity seems to override functional imperatives to address certain policy problems more effectively on a European scale (Hooghe and Marks, 2008)? In 
some instances, supranational actors such as the European Commission may still have been able to push for more European integration when it was shielded from too much public or electoral scrutiny (Schimmelfennig, 2014). This special issue devotes particular attention to the role of the courts in the continuation of European integration. Healthcare is a preeminent case in this respect. The CJEU has been identified as an influential actor in EU healthcare policies. The CJEU has been even described as "Ersatz legislator" (Lamping, 2005). The CJEU decided path-breaking verdicts on issues such as the trade of pharmaceuticals and cross-border patient mobility. However, even if a considerable amount of scholarly literature has often mentioned the potential influence of the CJEU (Kelemen 2013; Stone Sweet 2010), its actual impact has remained underexplored. Whether and how the CJEU can be a driving force of integration thus still deserves more attention in EU studies. This special issue therefore focuses specifically on the CJEU's role in European integration. This issue's focus is from various angles because the CJEU heavily depends on other actors to have any impact at all. Its preliminary rulings to explain a piece of EU legislation occur at the request of the national courts. The CJEU also relies on the same national courts for the application of its case law in legal cases. Additionally, the CJEU depends on political actors such as the European Commission and the member states to act according to the "voice of law", both practically and legally. An exploration of the role of the CJEU therefore requires a broader understanding of the relation between law and politics.

The papers in this special issue are selected to provide the necessary empirical overview of EU involvement in healthcare policies and to improve in particular the understanding of the relation between law and politics in the European integration process. This issue will answer the two key questions that are presented above. The descriptive question regarding whether a European healthcare union is in the making is first addressed from a general point of view. Tamara Hervey discusses whether and how EU health law has emerged as a distinct area of law. Anniek de Ruijter presents the historical evolution of the EU institutions that are involved with human health. The following contributions examine the EU's involvement in healthcare policies in one of the three different tracks. Scott Greer and Olga Löblová focus on the role of the EU in the public health-related issues of communicable diseases and Health Technology Assessment (HTA). Three contributions explore the emerging role of the EU in healthcare because of the application of internal market principles to national 
healthcare systems, in particular by the CJEU. The CJEU verdicts on cross-border patient mobility since 1998 constitute major instances of legal interference into national healthcare systems. Therefore, these contributions focus specifically on these verdicts, their implementation, and also the 2011/24/EU directive on the application of patients' rights in cross-border healthcare, which attempted to codify CJEU case law. These contributions also seek to address the scarcity of studies concerning the implementation of healthcare-related EU law (Lamping, 2013). In their contribution, Dorte Sindbjerg Martinsen and Juan Mayoral Diaz-Asensio examine the extent to which national courts refer to CJEU case law in Spain and Denmark. Hans Vollaard analyses whether and how territoriality, a key aspect of the politicolegal order of the Westphalian state, matters in the implementation of CJEU case law and the directive in the Netherlands and Belgium. Nikolay Vasev, Karsten Vrangbæk, and Filip Krepelka discuss the variegating implementation of the case law in the Central and Eastern European countries of Poland, Bulgaria, and the Czech Republic. The third track of EU involvement in healthcare policies is explored by Rita Baeten and Bart Vanhercke, who show the extent to which this track is part of the recommendations concerning national budgets and national economic policies in the framework of the European Semester.

\section{Is a European healthcare union in the making?}

The overall conclusion that can be derived from the contributions that are presented here is that, however fragile, a European healthcare union is emerging. EU involvement in healthcare policies is no longer a patchwork that is only known under other labels, such as the internal market. EU involvement in healthcare policies is no longer only justified by and based on its contribution to economic growth, budgetary stability, or improving the health conditions of the entire population. EU involvement in healthcare policies is currently also specifically labelled as healthcare and also motivated by making ill people better regardless of their income or status in the EU area. In her contribution, Hervey thus shows how the legal regulation of healthcare in the EU is no longer a matter of EU law that is applied to healthcare or healthcare law that is applied to the EU. Instead, a distinct area of EU health law has been narrated into existence over the years (Hervey, 2016). Additionally, De Ruijter maps the consolidation of health expertise in the European Union (De Ruijter 2016). The 
contribution examines the different EU institutions and how a distinct health expertise was gradually formed and became critical to how the field was defined and its scope was set. The Commission is at the centre of the process, although not as a unitary actor. De Ruijter details how healthcare historically was spread across different DGs and Commissioners. Because of the BSE crisis, the DG SANCO (Directorate General for Food and Health Safety - and the predecessor of the DG SANTÉ) came into being in 1997. With SANCO, healthcare was marked as an independent portfolio, but that did not end internal power struggles within the Commission. Compared with other DGs, SANCO has been characterized as politically weak (Greer 2009; De Ruijter 2016). Nevertheless, SANCO took over the drafting of the patients' rights directive from the DG MARKT after the European Parliament voted to negotiate crossborder healthcare as part of the service directive (De Ruijter 2015, 234-235; Martinsen 2015, 148-149). This negotiation implied a shift in policy discourse and placed healthcare expertise on the table to draft and negotiate the directive. De Ruijter also notes how health expertise has evolved into Union agencies and committees and has become a distinct area to be addressed in the European Parliament's committee system and by member states' healthcare attachés in the relevant Council working groups. The institutional structure of the Union has thus given a certain voice to and consolidation of health expertise.

The contribution of Greer and Löblová shows that communicable disease control and health technology assessments have become important parts of EU healthcare integration (Greer and Löblová 2016). Given its considerable size, multi-dimensional nature, and complexity, the healthcare sector always involves actors from other policy areas with other policy principles. Thus, health technology assessment has appeared on the Union agenda as the solution to various problems, such as cost-containment of the healthcare sector. In some instances, healthcare actors could take the lead, however. For instance, Greer and Löblová identify the SARS outbreak in 2003 as the tipping point from which the health Commissioner could set a Community agenda for common actions against communicable diseases.

The regulation of pharmaceuticals and to some extent health professionals in the internal market have been rather exceptional instances of the European involvement of healthcare actors since the 1960s and 1970s. The regulation of cross-border healthcare has been a much larger impetus for healthcare actors and principles to emerge at the EU level but only since the late 1990s. To be fair, since 1958 onwards, European law included arrangements 
for cross-border labourers to receive healthcare outside their system of affiliation under certain conditions. However, these arrangements were part of the coordination of social security systems in the internal market, and they were mostly addressed by ministers of social affairs rather than health ministers. In its series of verdicts on cross-border healthcare since 1998, the CJEU allowed patients to receive reimbursement of most extramural crossborder healthcare without prior authorization, if it was covered by the health insurance package at home. Under certain conditions, patients could even also receive reimbursement for expensive and intramural care that was obtained abroad according to CJEU case law. The CJEU verdicts constituted a major incentive for health ministers and their civil servants to start discussing EU involvement in healthcare policies, initially mostly informally but eventually, also formally (Hervey and Vanhercke, 2010). Health ministers did not want to leave EU involvement in healthcare to the judges and actors from other policy areas with different policy principles. In 2004, the DG MARKT of the European Commission attempted to codify the CJEU case law in a general directive concerning the free movement of services, and a wide range of actors in the European Parliament and member states insisted that healthcare services should be arranged in a separate piece of legislation because of their specific nature. The health ministers subsequently agreed in 2006 on a set of common values and principles and emphasized the non-economic tenets of their healthcare systems, such as quality, safety, evidence-based ethical care, patient involvement, redress, privacy, and confidentiality (Council conclusions 2006). Furthermore, relying on 'soft' charters, declarations, conventions and recommendations by the EU, the Council of Europe and the World Health Organisation, the member states agreed in 2007 in the Lisbon Treaty to enshrine patients' rights by referring to the binding Charter of Fundamental Rights of the EU. Accordingly, this charter states that "everyone has the right of access to preventive health care and the right to benefit from medical treatment under the conditions established by national laws and practices". A certain commonality in patients' rights has thus emerged in the EU.

The DG SANCO of the European Commission eventually proposed in 2008 the "directive on the application of patients' rights in cross-border healthcare". ${ }^{3}$ After years of protracted negotiations, the European Parliament and the Council of the European Union (in which each member state is represented by a minister) agreed on a substantially modified directive 
(Martinsen 2015, see also below). Even if the reduction of legal uncertainty for patients who seek cross-border healthcare has been a main motive to adopt this directive, several observers have foreseen further court cases because of remaining ambiguities (Greer, 2013). As a result, not only the directive but also additional CJEU case law may be instrumental to advance some type of commonality in patients' rights concerning issues such as informed choice, reimbursement, and aftercare. These instruments are dependent on the extent to which member states implement EU (case) law. Therefore, three contributions in this special issue examine whether and how the member states have implemented CJEU case law and the directive concerning cross-border healthcare because we still have limited knowledge regarding the actual impact of the CJEU at the national level.

Martinsen and Mayoral Diaz-Asensio examine the impact of this process of judicialization in Denmark and Spain (Martinsen and Mayoral Diaz-Asensio 2016). They investigate the expost judicial, administrative and political responses to legal integration and examine in particular the extent to which national courts activate EU law in their national proceedings. The comparison of Denmark and Spain show that the two universalistic healthcare models have so far proved resistant to judicialization and that there is a wide discrepancy between legal integration and the de facto rights that it has produced at the national level. The patient empowerment that was expected because of CJEU jurisprudence is not confirmed by the two case studies (Martinsen and Mayoral Diaz-Asensio 2016). Vollaard examines the extent to which CJEU jurisprudence and the patients' rights directive, as part of a larger process of the liberalization of cross-border healthcare in the EU's internal market, led to the end of territoriality in the provision of healthcare (Vollaard 2016). Conceptually, the contribution offers a distinction between the legal principle of territoriality, a core feature of the state, and territoriality as a political strategy of controlling people and phenomena such as patient mobility. In empirical terms, Vollaard shows that EU law, including CJEU jurisprudence, has created a new domain for cross-border healthcare on a European scale. Moreover, although EU law has undermined the legal principle of territoriality, member states also reinstated territorial control on a European scale through the patients' rights directive. Territorial control is also still an integral part of the member states' organization of healthcare, as reflected by the way EU law on cross-border healthcare has been implemented even in the Netherlands and Belgium, which are founding members with 
considerable experience in cross-border healthcare. Finally, the contribution by Vasev, Vrangbæk and Krepelka examines the impact of CJEU jurisprudence on cross-border healthcare in Central and Eastern European member states (Vasev, Vrangbæk, and Křepelka 2016). They compare judicialization in the new member states with the previous findings of Obermaier, who identified a certain compliance with the jurisprudence in the UK, Germany and France (Obermaier 2009). In contrast to Obermaier, Vasev, Vrangbæk and Křepelka find that judicialization has not been able to drive change to any notable extent in the new member states that were examined. The case law has either been ignored or has only led to limited compliance. Together, these three contributions substantiate the contained nature of compliance with jurisprudence, as established in the seminal work of Lisa Conant (Conant 2002; Conant 2001). This compliance leaves the legal commonality of patients' rights in cross-border healthcare rather fragile because it remains highly dependent on the actual application on the ground.

Baeten and Vanhercke bring us to the new avenue of EU healthcare integration through the recently intensified EU's budgetary and economic surveillance of the member states (Baeten and Vanhercke 2016). The institutional landscape has changed regarding EU surveillance. Decisions are made by the troika/institutions of the European Central Bank, the International Monetary Fund (IMF) and the Commission in this matter and are enacted primarily by the DG ECFIN, not by the DG SANTE. Even if Baeten and Vanhercke demonstrate the varying impact of this surveillance across the EU member states, it deeply intrudes into national healthcare policies. The impact is especially extensive for the countries that receive financial support from the EU and the IMF, which are the 'memorandum' countries of Romania, Greece, Ireland, Cyprus and Portugal. Tied by 'memorandums of understanding', these member states receive very detailed prescriptions on how to reform their healthcare sectors, including reduction of pharmaceutical spending, the number of hospitals, hospital beds and healthcare professionals. The year 2010 is identified as the point in time of the 'game-change'; the financial and economic crises created a window of opportunity for the economic actors to apply their solutions to the healthcare sector. We find that the DG ECFIN is on the centre stage and applies austerity measures to the healthcare sector. With this 'game-change', health system reforms are currently the core of the European economic governance procedure, but many actors are missing in defining the scope and limits of this 
intervention, such as national healthcare authorities, the DG SANTE, the European Parliament, and the national parliaments, among others. The 'grand recession' thus marks a turn in the evolving healthcare Union and challenges its emerging content (De la Porte and Natali 2014; Martinsen and Vollaard 2014). Fiscal constraints impede positive healthcare integration while simultaneously impacting considerably the scope and conditions of national healthcare systems (Scharpf 2002). Additionally, in contrast to cross-border patient mobility and public health, EU involvement is primarily dominated by non-health actors, which leaves the European healthcare union rather fragile and fragmented. Nevertheless, the austerity face of EU involvement in healthcare may also be a first integrative step towards common financing for national healthcare systems (cf. Vollaard et al., 2015). At least for countries with fiscal stress, the EU has provided loans and financial guarantees to maintain the state apparatus and the healthcare system.

The drivers of a European healthcare union in the making: the dynamics of law and politics

The European healthcare union has emerged and evolved despite member states insisting that the organization of welfare should primarily remain a national responsibility (Leibfried 2010; Ferrera 2005). This evolution presents the classic question of European integration. Which driving dynamics have been at play and explain the emerging features of a European healthcare union? Research on EU healthcare integration indicates different dynamics and institutions in explaining the emerging field. One line of research focuses on crises- or problem-driven dynamics where the outbreak of communicable diseases, such as AIDS or the BSE crisis, or shared public health problems, such as obesity, have pushed for European solutions. In this expansion of Union involvement, the European Commission is presented as a successful entrepreneur that seized the window of opportunity and expanded EU power and provisions (Lamping and Steffen 2009; Steffen 2012; Kurzer and Cooper 2011; Greer and Löblová 2016, this volume). Confirming the neo-functionalist focus on the stimulating role of non-state actors, the DG SANTE is presented here as a key institution that accepted political leadership and ensured EU involvement in public health. Similarly, the influence of other non-state actors, such as professional medical networks, have been noted (Trubek et al., 2009). 
In recent decades, the politicized issue of identity has begun to overshadow problem-solving as a key motive in discussions on European integration (Hooghe and Marks, 2009). The greater public is also no longer indifferent to what (supranational) elites have decided. The era of permissive consensus has thus come to an end. Greer and Löblová couple neofunctional spill-over dynamics with Kingdon's multiple streams approach to identify the impact of politicization and dissensus. In the two processes of agenda-setting that they examine, Greer and Löblová cannot identify the constraining dissensus of politics as presented by Liesbeth Hooghe and Gary Marks (Hooghe and Marks 2009), but they note that political dissensus may still apply in the decision-making phase of integration. The neofunctionalist explanations above primarily concern issues of public health; these issues involve less reluctance among governments and the greater public concerning integration. The financing and organizing of healthcare may be a different story, however. Kingdon's multiple streams approach, or variations of it, can still be helpful to explain whether a European healthcare union may yet emerge in the organized chaos of the EU despite a Eurosceptic mood (see also Vollaard and Martinsen 2014; Baeten and Vanhercke 2016).

As noted above, the CJEU has played an important role in the integration of cross-border healthcare. The CJEU has constituted a major motivation for the making of EU health law. Tamara Hervey argues that when we can explain how EU health law emerged as a field, we must examine how and by whom the law was narrated (Hervey 2016). Hervey notes that narration is the core to the evolving EU health regulation, which is a process through which principles, content and themes are discerned and articulated. For the emerging EU healthcare law, three main groups have been involved, namely, the legislature, the courts and the academy. The national courts and the CJEU have been key actors in deciding the content and scope of the narration, but they have been joined by the national and EU legislatures and to a lesser extent, the academy. Each set of actors have their own interpretation of what constitutes the meaning of law, and they do not always agree. Especially the legislatures have insisted on 'objective public interest' to be part of the narration to protect the organization and capacity of national health care systems. The emphasis on 'objective public interest' has increasingly been recognized by the CJEU. The narration of EU healthcare law is thus also a process through which both the scope and the limits of EU regulation are defined. The narration of EU healthcare law is not a linear line of 
progression towards more EU regulation. In addition, the application of the narration and its implementation and impact is not a given or automatic but depends on its clarity, i.e., which Hervey terms 'structural coherence'.

Legal integration is also the focus of another line of research, in particular the field of crossborder healthcare (Greer 2006; Martinsen 2005). Here the litigants, courts, and particularly the CJEU come to the forefront and explain the expansion of EU competences. The CJEU applied internal market principles to the healthcare area, and for almost a decade, progressive legal interpretations were able to advance what politics could or would not. However, the political reluctance towards any EU intrusion into national healthcare systems left its mark on both CJEU case law and its implementation. The integration process of Union cross-border healthcare details the dynamics of law and politics as they unfolded over time. Concerning the law, CJEU case law intervened in a highly sensitive political field. The CJEU likely did not anticipate the strong reactions against its legal moves. As noted by Greer and Jarman, the Court probably did not know much concerning the substance of healthcare or did not give much consideration to the impact of and responses to entering a 'complex, politically difficult and very expensive area' (Greer and Jarman 2012, 267). Regarding politics, healthcare ministers first strongly opposed CJEU intervention in the policy field but were soon unable to agree on a political response to legal integration. The member states waited for the Commission to take the initiative, but the Commission responded with 'deafening silence' (Palm et al. 2000, 78). Apparently, the European executive was crippled with internal disagreements between its Commissioners and DGs, and the European Parliament warned the Commission of the political defeat that it would suffer if it did not establish the appropriate balance among the principles of the internal market through subsidiarity (Martinsen 2015, 147-148).

Meanwhile, the European Court continued to develop its interpretations on cross-border healthcare. As the rulings developed, their scope was gradually clarified. On the one hand, the Court applied its reasoning to all healthcare systems. On the other hand, the CJEU also established that deviations from the free movement principles were justifiable under certain conditions, thus 'fine-tuning' its jurisprudence (De Ruijter 2015, 228; Obermaier 2009). In July 2008, the Commission could finally present its proposal on patients' rights in crossborder healthcare. It was clear from early on that a majority of politicians in the Council and 
the European Parliament wanted to maintain national control with a large scope of healthcare treatments through prior authorization. The adopted version of the Directive thus came to modify the impact of the Court's jurisprudence because it allowed for the use of prior authorization for not only hospital care but also highly specialized and expensive outpatient care - as defined by the member states. The Commission was highly unsatisfied with this political development and found that the extensive use of prior authorization in fact departed from the case law of the Court (Martinsen 2015, 171-172).

At the same time, the CJEU, however, has taken a more 'tempered' approach and apparently adapted its behaviour to the European legislator (Hatzopoulos and Hervey 2013). Even during the decision-making process between the Council and the European Parliament, the CJEU adapted its reasoning concerning an extended use of prior authorization (Baeten and Palm 2013, 394). ${ }^{4}$ The law and politics dynamics that were involved in constructing the emerging healthcare Union thus demonstrate that legal integration was highly important from the outset, but the CJEU did not do it alone. The course of legal integration was occasionally modified and proved responsive to political positions. The CJEU did not need to adapt its position because its previous rulings were based on primary law, which from a formal point of view, can only be overridden through a Treaty amendment. Therefore, the adaptive behaviour of the Court is even more noteworthy, as observed by Hervey and McHale: "[t]he CJEU is not, of course, obliged to follow the legislature where it interprets Treaty provisions such as Article 56 TFEU, but in practice it usually does so" (Hervey and McHale 2015, 91). This implies a more fine-grained relation between law and politics than a simple neo-functionalist reading would suggest. This relation is where European politics plays a decisive role and where the Court is not politically blind but even looks for 'political guidance' on how to apply more open Treaty provisions (Baeten and Palm 2013, 394).

The relation between law and politics is not only dynamic at the law-making stage. As illustrated in the three contributions concerning the implementation of CJEU case law and the patients' rights directive, the healthcare union also consists of tensions and contradictions between the rules that emerge at the 'federal' level and how they are responded to at the national level. Moreover, the dynamic between law and politics plays out rather differently across and within member states because national courts and national governments vary in their application of EU law. 
To conclude, the contributions of this volume demonstrate that the emerging healthcare Union is a co-operative system that combines self-rule and shared rule (Vollaard, Van de Bovenkamp, and Martinsen 2015). A large part of healthcare is still organized by the member states, and the impact of the shared rule depends on its national implementation. At the same time, the two levels are intertwined, with overlapping competences through continuous interaction and disputes, and they attempt to settle the division of labour and define the line between shared rule and self-rule. The contributions of this volume present a broader set of actors, institutions and dynamics in the making of a European healthcare union than what arises from the interactions among an entrepreneurial Commission, a dynamic Court and reluctant national politicians suggest. This volume notes that the dynamics differ depending on where we are in the policy-making process and which subarea of healthcare we investigate. Together, the different pieces substantiate that when examining the emergence, content and outreach of a policy field, the way is long and winding from policy idea through politics to output.

Although fragile, a European healthcare union is in the making. Healthcare can be produced, consumed and provided across the internal borders of the EU. A distinct field of law and set of institutions co-regulate healthcare, whereas common values, rights, and principles have been agreed on. Certainly, national healthcare systems have not been fully integrated into a single European healthcare system. Additionally, other policy actors and principles still leave their mark on EU involvement in healthcare policies. Moreover, in practice, compliance with EU legislation and case law on patient mobility remains rather variegated across and within member states. However, the EU has become an extra, although thin, primary regulatory layer in organizing, financing and providing healthcare (Vollaard, Van de Bovenkamp, and Martinsen 2015).

\section{Endnotes}

1. Financial support from the Danish Research Council project No. 10-079675/FSE is gratefully acknowledged.

2. Directive 2011/24/EU of the European Parliament and of the Council of 9 March 2011 on the application of patients' rights in cross-border healthcare, OJ L 88, 4 April 2011.

3. Proposal for a Directive of the European Parliament and of the Council COM (2008) 414 of 2nd July 2008 on the application of patient rights in cross-border healthcare. 
4. See, among others, C-512/08 European Commission v French Republic [France] [2010] ECR I-8833 and Case C-169/07 Hartlauer Handelsgesellschaft mbH $\vee$ Wiener Landesregierung and Oberösterreichische Landesregierung [2009] ECR I-1721. Opinion of the Advocate-General of 9 September 2008, see footnote 44 of the opinion.

\section{About the Authors}

Hans Vollaard is lecturer in Dutch and European Politics at Leiden University, the Netherlands. He obtained his PhD in political science at the same university. Focal points in his recent research are European disintegration, the Europeanization of the Netherlands, local democracy, and European health policies.

Dorte Sindbjerg Martinsen is Professor (MSO) at University of Copenhagen, Department of Political Science. Her research focuses on EU welfare policies, investigating integration, national implementation of and compliance with EU social policies, including health care. Her recent work examines the interaction between legal integration and legislative politics in the European Union, published in the book "An Ever More Powerful Court? The Political Constraints of Legal Integration in the European Union" (2015) with Oxford University Press and in the article in Comparative Political Studies "Judicial Influence on Policy Outputs? The Political Constraints of Legal Integration in the European Union" (2015) vol. 48:12, 1622-1660.

\section{References}

Baeten, R. and Palm, W. (2013) 'The Compatibility of Health Care Capacity Planning Policies with EU Internal Market Rules', in J.W. van de Gronden, E. Szyszczak, U. Neergaard and M. Krajewski (eds.), Health Care and EU Law. The Hague: T.M.C. Asser Press, pp. 389-413.

Baeten, R. and Vanhercke, B. (2016) 'Inside the black box: the EU's economic surveillance of national healthcare systems'. Comparative European Politics.

Conant, L. (2001) 'Europeanization and the Courts: Variable Patterns of Adaptation among National Judiciaries', in M.G. Cowles, J. Caporaso and T. Risse (eds.), Transforming

Europe: Europeanization and domestic change. Ithaca and London: Cornell University Press, pp. 97-115.

Conant, L.J. (2002) Justice Contained, Law and Politics in the European Union, Ithaca: Cornell University Press.

De la Porte, C. and Natali, D. (2014) 'Altered Europeanisation of pension reform in the context of the great recession: Denmark and Italy compared'. West European Politics $37(4)$. 
De Ruijter, A. (2015) 'A Silent Revolution: The Expansion of EU Power in the Field of EU Power in the Field of Human Health. A rights-based analysis of EU Health law \& policy', in. Amsterdam: University of Amsterdam.

De Ruijter, A. (2016) 'The Institutional Consolidation of EU Human

Health Expertise'. Comparative European Politics.

Ferrera, M. (2005) The boundaries of welfare: European integration and the new spatial politics of social protection, Oxford: Oxford University Press.

Greer, S. and Jarman, H. (2012) 'Managing risks in EU health services policy: spot markets, legal certainty and bureaucratic resistance'. Journal of European Social Policy 22(3):259-72.

Greer, S. and Löblová, O. (2016) 'European integration in the era of permissive dissensus: Neofunctionalism and agenda-setting in European health technology assessment and communicable disease control'. Comparative European Politics.

Greer, S.L. (2006) 'Uninvited Europeanization: neofunctionalism and the EU in health policy'. Journal of European Public Policy 13(1):134-52.

Greer, S.L. (2009) The changing world of European health lobbies: Oxford: Oxford University Press.

Hatzopoulos, V. and Hervey, T. (2013) 'Coming into line: the EU's Court softens on crossborder health care'. Health Economics, Policy and Law 8(01):1-5.

Hervey, T. (2016) 'Telling stories about European Union Health Law: The emergence of a new field of law'. Comparative European Politics.

Hervey, T. and McHale, J. (2015) 'European Union Health Law: Themes and Implications', in. Cambridge: Cambridge University Press.

Hooghe, L. and Marks, G. (2009) 'A postfunctionalist theory of European integration: From permissive consensus to constraining dissensus'. British Journal of Political Science 39(01):1-23.

Kelemen, R.D. (2013) 'Judicialisation, Democracy and European Integration'. Representation 49(3):295-308.

Kurzer, P. and Cooper, A. (2011) 'Hold the croissant! The European Union declares war on obesity'. Journal of European Social Policy 21(2):107-19.

Lamping, W. (2005) 'European integration and health policy: a peculiar relationship', in M. Steffen (ed.), Health Governance in Europe. Issues, challenges and theories. London: Routledge.

Lamping, W. and Steffen, M. (2009) 'European Union and Health Policy: The "Chaordic" Dynamics of Integration*'. Social Science Quarterly 90(5):1361-79.

Leibfried, S. (2010) 'Social Policy: Left to the Judges and the Markets?', in H.S. Wallace, W. Wallace, M.A. Pollack, H. Wallace and A.R. Young (eds.), Policy-Making in the European Union. Oxford: Oxford University Press, pp. 253-83.

Martinsen, D.S. (2005) 'Towards an internal health market with the European Court'. West European Politics 28(5):1035-56.

Martinsen, D.S. (2015) An Ever More Powerful Court? The Political Constraints of Legal Integration in the European Union, Oxford: Oxford University Press.

Martinsen, D.S. and Falkner, G. (2011) 'Social Policy: Problem-Solving Gaps, Partial Exits, and Court-Decision Traps', in G. Falkner (ed.), The EU's Decision Traps. Comparing Policies. Oxford: Oxford University Press, pp. 128-45.

Martinsen, D.S. and Mayoral Diaz-Asensio, J. (2016) 'A Judicialisation of Healthcare Policies in Denmark and Spain? The Universalist Healthcare Model Meets the European Union '. Comparative European Politics.

Martinsen, D.S. and Vollaard, H. (2014) 'Implementing Social Europe in Times of Crises: Reestablished Boundaries of Welfare?'. West European Politics 37(4):677-92. 
Obermaier, A. (2009) 'The End of Territoriality? The Impact of ECJ Rulings on British, German and French Social Policy', in. Surrey: Ashgate.

Palm, W., Nickless, J., Lewalle, H., and Coheur, A. (2000) 'Implications of recent jurisprudence on the co-ordination of health care protection systems', in. Bruxelles: AIM: Association Internationale de la Mutualite, pp. 1-170.

Scharpf, F.W. (2002) 'The European Social Model: Coping with the Challenges of Diversity'. Journal of Common Market Studies 40(4):645-70.

Steffen, M. (2012) 'The Europeanization of public health: how does it work? The seminal role of the AIDS case'. Journal of health politics, policy and law 37(6):1057-89.

Stone Sweet, A. (2010) 'The European Court of Justice and the Judicialization of EU Governance'. Living Reviews in European Governance 5(2).

Vasev, N., Vrangbæk, K., and Křepelka, F. (2016) 'The End of Eastern Territoriality? CJEU Compliance in the New Member States'. Comparative European Politics.

Vollaard, H. (2016) 'Changing territoriality in the EU healthcare union'. Comparative European Politics.

Vollaard, H. and Martinsen, D.S. (2014) 'Bounded Rationality in Transposition Processes: The Case of the European Patients' Rights Directive'. West European Politics 37(4):711-31.

Vollaard, H., Van de Bovenkamp, H., and Martinsen, D.S. (2015) 'The making of a European healthcare union: a federalist perspective'. Journal of European Public Policy(aheadof-print):1-20.

Vollaard, H., van de Bovenkamp, H.M., and Vrangbæk, K. (2013) 'The emerging EU quality of care policy: From sharing information to enforcement'. Health Policy 111(3):22633. 